\title{
Growth and production of the amphipod Parhyale basrensis (Talitridae) in the Shatt al-Arab region
}

\author{
Malik H. Ali, Salman D. Salman \\ Department of Marine Biology, Marine Science Centre, University of Basrah, Basrah, Iraq
}

\begin{abstract}
Life history data for the intertidal amphipod Parhyale basrensis Salman was collected, from April 1983 to September 1984, from an area near the Al-Chibassy tributary of the Shatt al-Arab River at Basrah, Iraq. Population density in the Shatt al-Arab region ranged from 928 to $12512 \mathrm{~m}^{-2}$ and mean annual density was $3842 \mathrm{~m}^{-2}$ Growth rate of the generation which survived only the summer was $0.027 \mathrm{~mm} \mathrm{~d}^{-1}$ for males and $0.026 \mathrm{~mm} \mathrm{~d}^{-1}$ for females, and of the over-wintered generation was 0.024 and $0.019 \mathrm{~mm} \alpha^{-1}$ for males and females respectively. Mortality rate was higher amongst the overwintering generation $\left(0.200 \mathrm{yr}^{-1}\right)$ than the summer generation $\left(0.048 \mathrm{yr}^{-1}\right)$. Mean annual biomass of the population was $1.82 \mathrm{~g} \mathrm{dwt} \mathrm{m}^{-2}$, annual production was $5.58 \mathrm{~g} \mathrm{dwt} \mathrm{m}^{-2}$ and P:B ratio was 3.06 .
\end{abstract}

\section{INTRODUCTION}

The intertidal talitrid amphipod Parhyale basrensis Salman is widely distributed in the Shatt al-Arab River, Iraq. The River in this region contains oligohaline brackish water, characterized by few species of however high population density (McLusky 1971). In recent years the amphipod was noticed to occur in much higher densities than before which suggested an unusually high productivity. This led to a program for investigating the biological significance and role of the species in the Shatt al-Arab River.

Since its original description (Salman 1986) the species has been under intensive study. In an earlier study (Ali \& Salman 1986) it was found that Parhyale basrensis has a semi-annual life history extending from May of one year to June of the next year, giving a maximum life span of 13 to 14 mo. The breeding season extends from late November or December with recruitment starting at the beginning of May. The objective of the present study was to estimate the growth and production of $P$. basrensis

\section{MATERIALS AND METHODS}

This study is based on samples collected monthly from the intertidal zone in the period between April 1983 and September 1984. The sampling site was near Al-Chibassy tributary of the Shatt al-Arab River, Iraq
(Fig. 1), just opposite the Silo of Basrah. Two quadrats $(25 \times 25 \mathrm{~cm})$ were taken on each occasion. After killing and preserving in $4 \%$ formalin, amphipods Parhyale basrensis were sorted through a $0.425 \mathrm{~mm}$ mesh-sized sieve. This mesh-size was found to be small enough to retain all stages of the amphipod. The amphipods were then grouped into $1 \mathrm{~mm}$ total length size classes and different cohorts separated by probability paper plotting (Harding 1949, Cassie 1954). Density and growth were determined by following the change in numbers and mean lengths of each generation over successive sampling periods.

To estimate monthly mean biomass and mean weight increments, the mean lengths of the amphipods were converted to mean weight using an empirical lengthweight regression equation. For this purpose live amphipods of different sizes, ranging between 1.5 and $12 \mathrm{~mm}$, were collected in May 1986. Each individual was anaesthetized, measured for length from cephalon to telson to the nearest $1 \mathrm{~mm}$ and the dry weight determined after oven-heating at $60^{\circ} \mathrm{C}$ for $24 \mathrm{~h}$. Weights of the amphipods were measured to the nearest $0.01 \mathrm{mg}$ by a Sartorius-type balance. Instantaneous mortality rate $Z$ was calculated from the slope of the regression $\log _{10} \mathrm{~N}$ against time, and annual mortality rate was estimated as $1-\mathrm{e}^{-\mathrm{Z}}$ (Crisp 1984).

Annual mean biomass was calculated from the monthly means of biomass and used for computing the production-biomass ratio $(\mathrm{P}: \mathrm{B})$. The production of each generation and the total annual production were esti- 


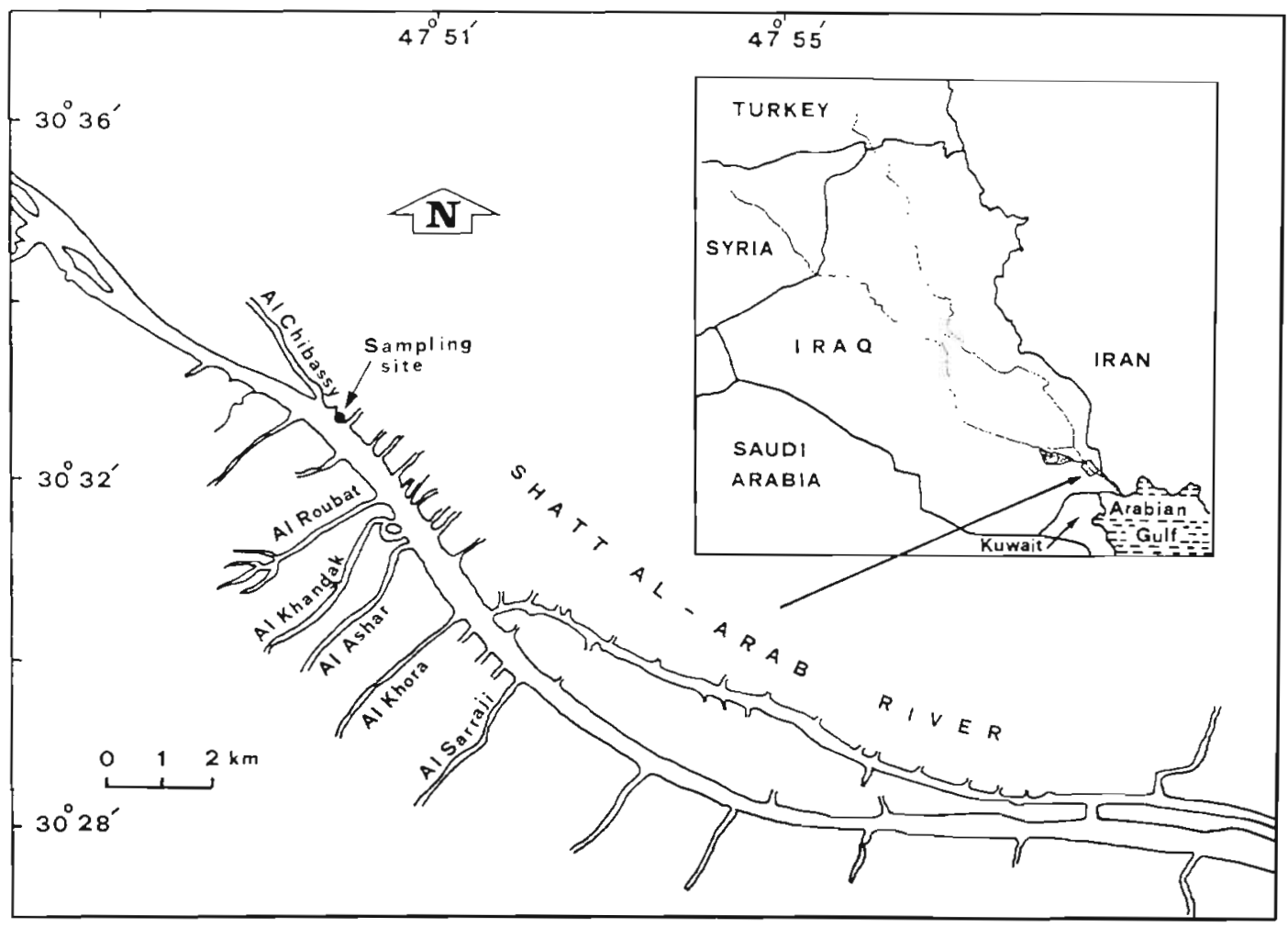

Fig. 1. Shatt al-Arab River, Iraq, showing the sampling site

mated by measuring the survivorships and mean weight increments of each generation separately using the expression of Crisp (1984):

$$
P=\sum_{t=0}^{t=n} \frac{\bar{N}_{t}+\bar{N}_{t+1}}{2} \bar{W}
$$

where $\bar{N}=$ mean population density at times $t$ and $t+$ $1_{i} \bar{W}=$ the mean weight increment between successive samples.

\section{RESULTS}

\section{Length-weight relation}

The length-weight relation for Parhyale basrensis was obtained from data on 120 specimens (Fig. 2) and expressed in the form of the following exponential equation:

$$
\begin{aligned}
& \log (\text { dry weight })=2.7217 \log (\text { length })-2.1919, \\
& r=0.9723
\end{aligned}
$$

\section{Density}

The population density of Parhyale basrensis reached a peak of $12512 \mathrm{~m}^{-2}$ in July 1983 (Fig. 3), declined steadily towards October, and sharply thereafter. The lowest total value of $928 \mathrm{~m}^{-2}$ was attained in
January and March 1984. A gradual increase occurred in April to June and a peak $\left(9104 \mathrm{~m}^{-2}\right)$ was found in July 1984 (i.e. lower than for the same month in 1983).

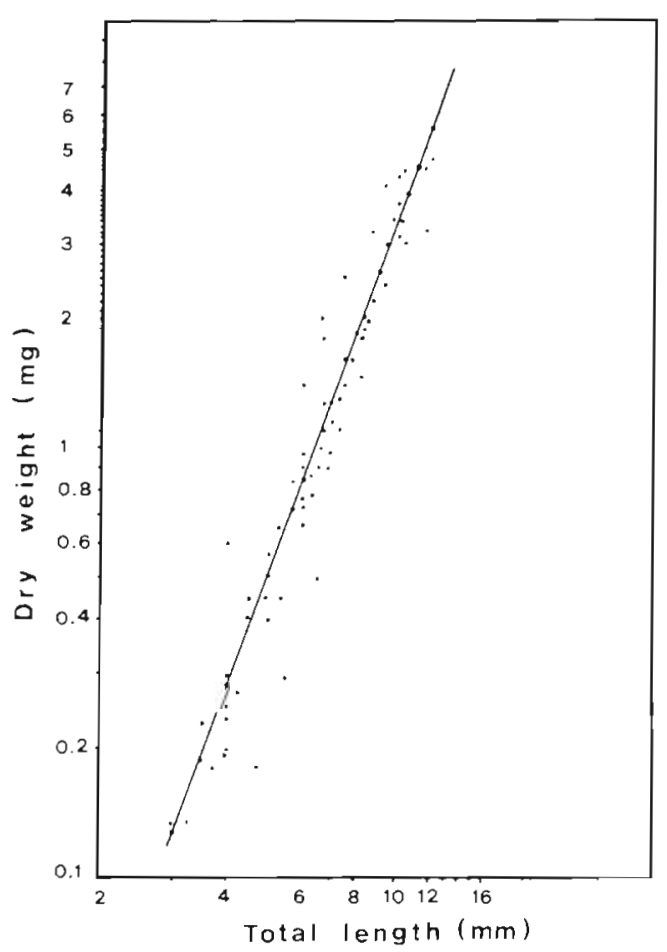

Fig. 2. Parhyale basrensis. Length-weight relation 
Fig. 3. Parhyale basrensis. Population density in the Shatt al-Arab region, from April 1983 to September 1984

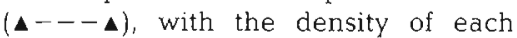
Generation A to E. Water temperature

(—) is given at the top of figure

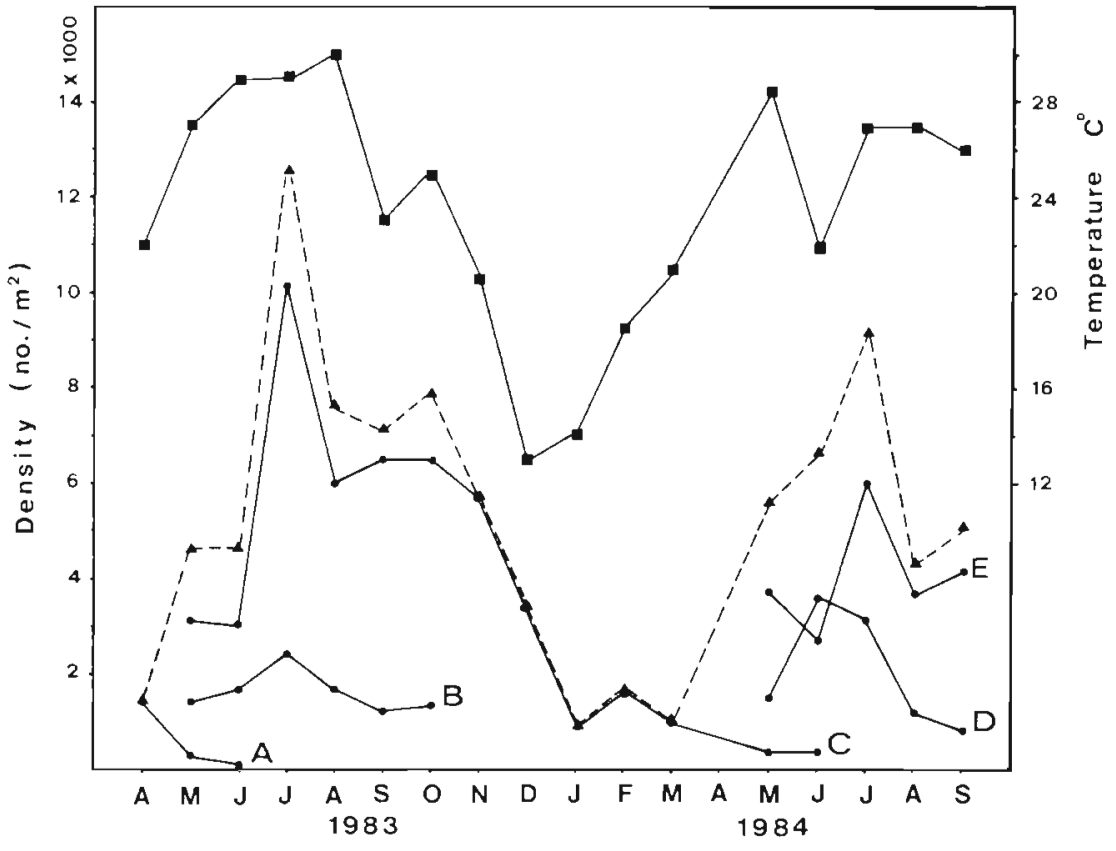

Growth

Growth trends based on mean length increments and the standard deviation of each generation during successive months are shown in Fig. 4. Members of the new generation (B), which was released after $11 \mathrm{Apr}$ 1983, grew from the hatching size of $1.5 \mathrm{~mm}$ total length to $5.1 \mathrm{~mm}$ for males and $5 \mathrm{~mm}$ for females by 11 May 1983. Average growth rate for males in this period was $0.17 \mathrm{~mm} \mathrm{~d}^{-1}$ and for females was $0.166 \mathrm{~mm} \mathrm{~d}^{-1}$. During May-June 1983 the growth rate of Generation $B$ was much slower than during the previous month. The life span of Generation B was found to be about density of this species.

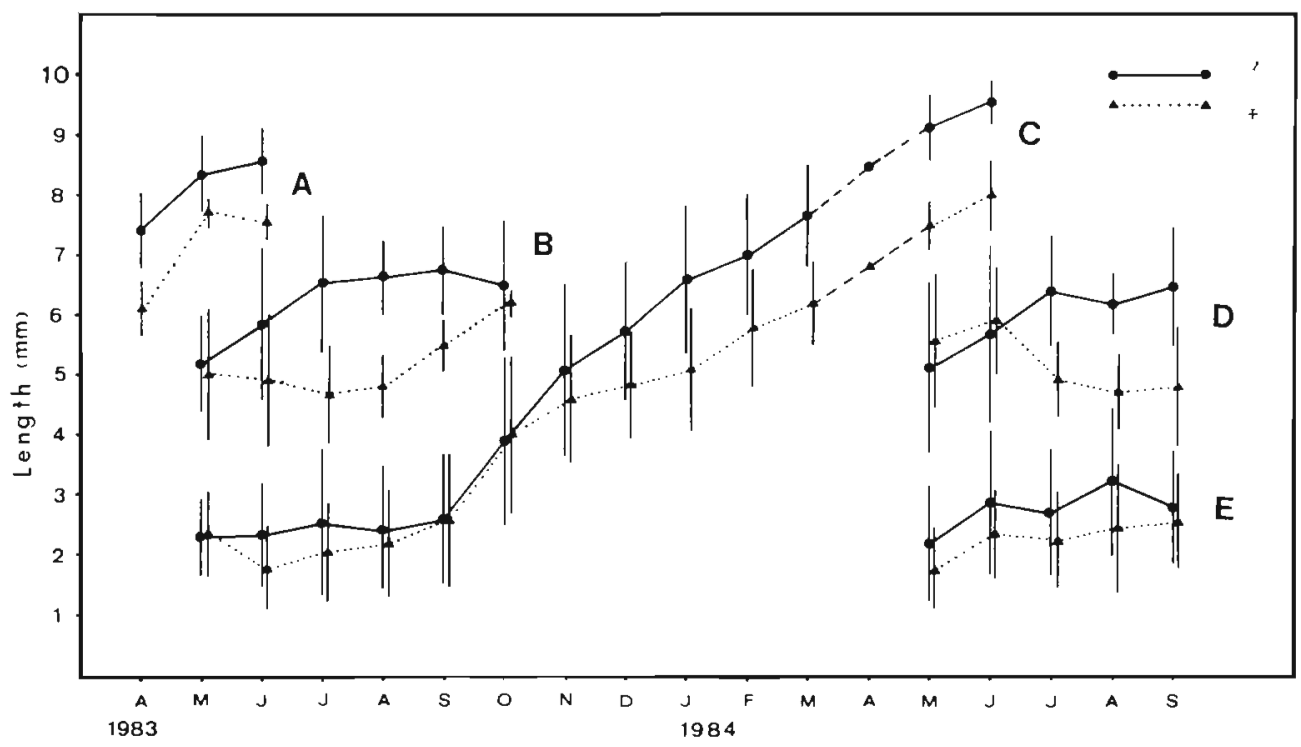

Fig. 4. Parhyale basrensis. Mean lengths and standard deviation of each generation in the Shatt al-Arab region for the period April 1983 to September 1984 


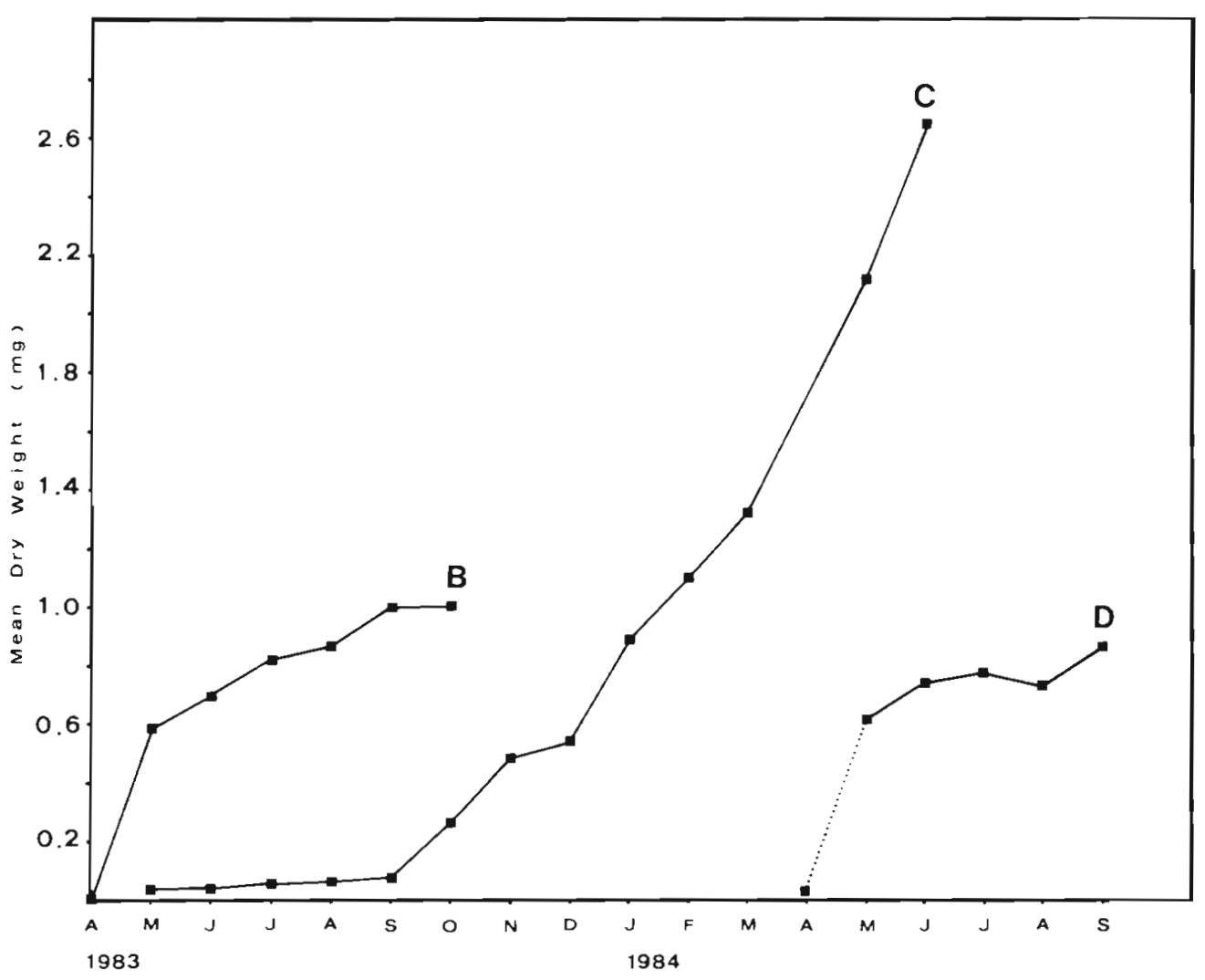

Fig. 5. Parhyale basrensis. Mean dry weight of Generations B, C and D in the Shatt al-Arab region over the sampling period

6 mo and the growth rate averaged throughout its life span was estimated to be $0.027 \mathrm{~mm} \mathrm{~d}^{-1}$ for males and $0.026 \mathrm{~mm} \mathrm{~d}^{-1}$ for females. Generation $\mathrm{C}$ which was released at the beginning of May 1983, persisted to June 1984. Growth rate of Generation C was low at the beginning of its life, from May to September 1983, but faster growth occurred from September to November 1983, when the estimated growth rate was about $0.040 \mathrm{~mm} \mathrm{~d}^{-1}$ for males and $0.033 \mathrm{~mm} \mathrm{~d}^{-1}$ for females. The growth rate of this generation for the period from August 1983 to June 1984 was 0.024 and $0.019 \mathrm{~mm} \mathrm{~d}^{-1}$ for males and females respectively.

Mean weight increments between successive sampling periods for Generations B, C and D, as estimated from length-weight expressions, are given in Fig. 5. The rates of dry weight growth averaged throughout the lives of Generation $B$ and $C$ was estimated to be $0.0056 \mathrm{mg} \mathrm{d}^{-1}$ and $0.0095 \mathrm{mg} \mathrm{d}^{-1}$ respectively.

\section{Life-history table and mortality}

A life-history table for the Parhyale basrensis population was constructed by following the survivorship of Gemerations B and C combined. Due to the problem of continuous breeding only a segment of these genera- tions, starting from July 1983 and continuing to June 1984, was taken. The initial recruitment of Generation $C$ was assumed to be equal to that of Generation B $\left(8000 \mathrm{~m}^{-2}\right.$, see 'Discussion'). Intervals of 2 mo were taken for the survivorship estimates. The data on the survivorship obtained (Table 1) was in the form of an inverse hyperbola, which is a usual curve for most

Table 1 Parhyale basrensis. Life-history table of the population in the Shatt al-Arab River. $x$ : age class (2 mo intervals); $\mathrm{n}_{\mathrm{x}}$ : number entering age class; $\mathrm{l}_{\mathrm{x}}$ : number surviving at start of age interval $x_{i} d_{x}$ : number dying during age interval $x$ to $x+$ $1_{i} \mathrm{q}_{\mathrm{x}}$ : rate of mortality during the age interval $\mathrm{x}$ to $\mathrm{x}+1$ (multiply by 100 to convert to percentage mortality); $L_{x}$ : average number of individuals alive during the age interval $x$ to $x$ +1 ; $e_{x}$ : mean life expectation for individuals alive at start of age $x$ (units of $2 \mathrm{mo}$ )

\begin{tabular}{rrcrrrrr}
\hline $\begin{array}{c}\text { Age } \\
\text { group }\end{array}$ & $\mathrm{n}_{\mathrm{x}}$ & $\mathrm{I}_{\mathrm{x}}$ & $\mathrm{d}_{\mathrm{x}}$ & $\mathrm{q}_{x}$ & $\mathrm{~L}_{\mathrm{x}}$ & $\mathrm{e}_{\mathrm{x}}$ \\
\hline 0 & 16000 & 1.000 & 5904 & 0.369 & 13048 & 2.0495 \\
1 & 10096 & 0.631 & 2312 & 0.229 & 8940 & 1.9556 \\
2 & 7784 & 0.487 & 3192 & 0.410 & 6188 & 1.3880 \\
3 & 4592 & 0.287 & 3304 & 0.719 & 2940 & 1.0052 \\
4 & 1288 & 0.081 & 640 & 0.497 & 968 & 1.3012 \\
5 & 648 & 0.041 & 264 & 0.407 & 516 & 1.092 \\
6 & 384 & 0.024 & 384 & 1.000 & 192 & 0.500 \\
\hline
\end{tabular}




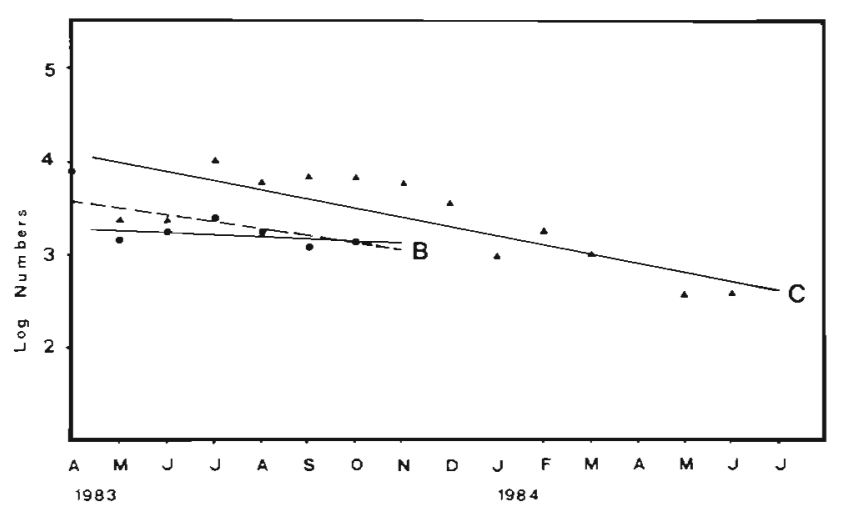

Fig. 6. Parhyale basrensis. Survivorship curves for Generations B and C at the Shatt al-Arab River during 1983/84. Broken line indicates curve of Generation B when initial calculated value of hatchlings $\left(8000 \mathrm{~m}^{-2}\right)$ in April was considered

invertebrates. The mortality rate of the 0 -age group was about $37 \%(2 \mathrm{mo})^{-1}$, and the peak of mortality, $72 \%(2 \mathrm{mo})^{-1}$, occurred in November-December.

Mortality rates of Generations $B$ and $C$ are shown in Fig. 6. Age-specific mortality rate $\mathrm{Z}$ for Generation $\mathrm{B}=$ $0.049 \mathrm{yr}^{-1}$ and for Generation $\mathrm{C}=0.224 \mathrm{yr}^{-1}$. Annual mortality rate was 0.048 and $0.200 \mathrm{yr}^{-1}$ for Generations $\mathrm{B}$ and $\mathrm{C}$ respectively.

\section{Biomass and production}

The mean monthly biomass of the population showed 2 peaks in 1983 (Fig. 7), the first in July and the second in October. In 1984 a peak was reached in June.
The estimated biomass in each of these 3 mo was 2.7 , 3.0 and $3.9 \mathrm{~g} \mathrm{dwt} \mathrm{m}^{-2}$, respectively. The biomass of each generation may be estimated from the mean monthly weight and the density of the generation (Table 2). The annual mean biomass of the population was $1.82 \mathrm{~g} \mathrm{~m}^{-2}$ inclusive of all generations. The mean biomass of Generations B and C was 0.78 and $1.04 \mathrm{~g}$ $\mathrm{m}^{-2}$ respectively. A comparison between the density curves (Fig. 3) and the biomass curves (Fig. 7) showed that the biomass peaks follow the density peaks.

The annual production, biomass and $\mathrm{P}$ : $\mathrm{B}$ ratio of the population and of each generation are given in Table 2 . The overwintering generation (C) was more productive (5.04 $\left.\mathrm{g} \mathrm{m}^{-2} \mathrm{yr}^{-1}\right)$ than the summer generation (B) $(0.73 \mathrm{~g}$ $\left.\mathrm{m}^{-2} \mathrm{yr}^{-1}\right)$. Most of the population production accumulated in October and November $\left(1.25\right.$ and $1.33 \mathrm{~g} \mathrm{~m}^{-2}$ respectively). Overall annual production was $5.58 \mathrm{~g}$ $\mathrm{m}^{-2}$. Turnover ratio, P: B, of Generation C was 5.1 times greater than that of Generation B. Overall annual turnover ratio was 3.06 .

In calculating maximum potential production (Table 2) the following assumptions were made: for Generation B sampled in May 1983, it was supposed that the entire generation recruited immediately after sampling on 11 Apr 1983. The length of these recruits was assumed to be the same as that of newly released juveniles of this species. Although no sampling was done in April 1984, the density curve of Generation D was constructed on the basis that, since the numbers of juveniles of this generation in May 1984 were almost equal to those of Generation B of May 1983, then they may have had the same density at the time of recruitment. It was further considered that Generation D lived

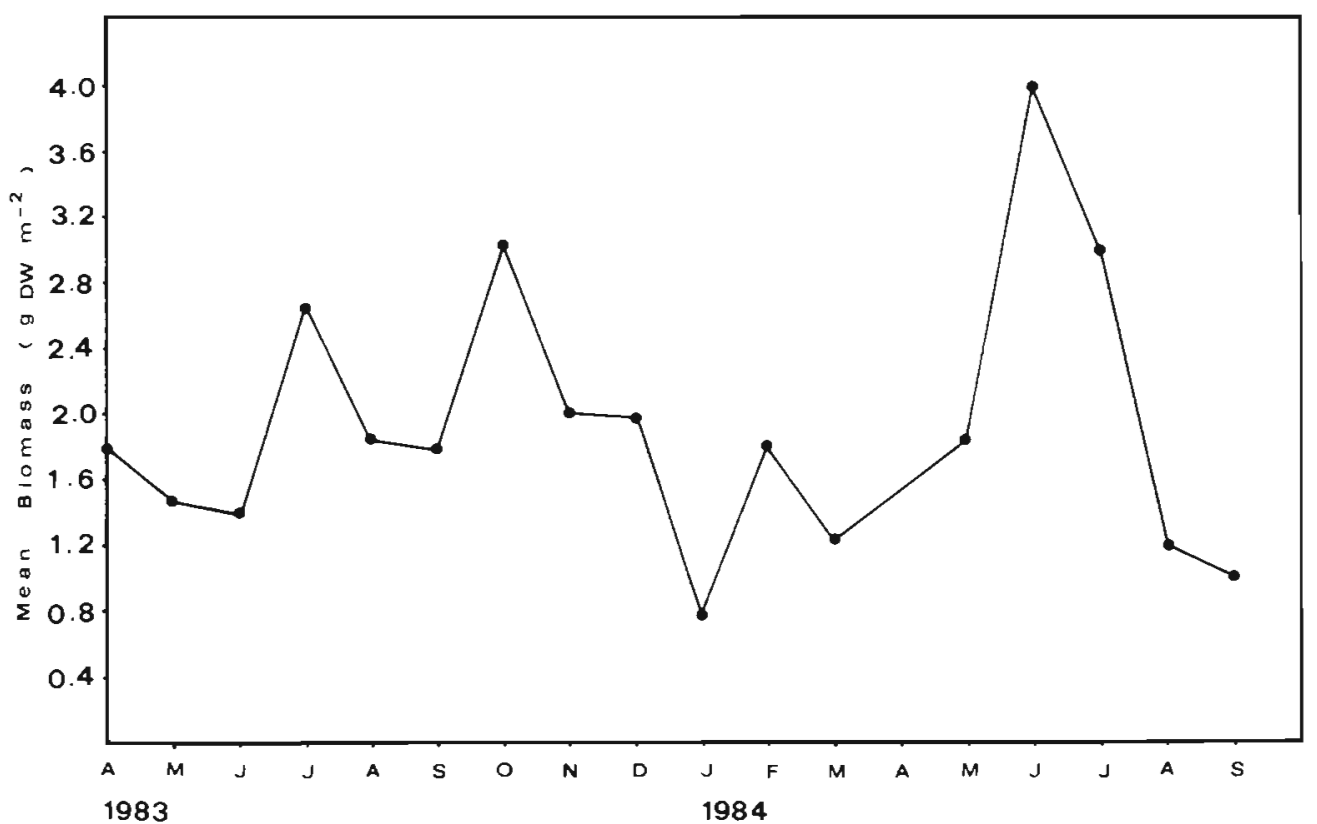

Fig. 7. Parhyale basrensis. Mean monthly biomass in the Shatt al-Arab region for the period April 1983 to September 1984 
Table 2. Parhyale basrensis. Summary of production data in the Shatt al-Arab River. Figures in parentheses represent maximum potential values

\begin{tabular}{|c|c|c|c|c|c|c|c|c|c|}
\hline $\begin{array}{l}\text { Mean annual bio- } \\
\text { mass }(\bar{B})\left(\mathrm{g} \mathrm{dwt} \mathrm{m}^{-2}\right)\end{array}$ & $\begin{array}{l}\text { Annual production } \\
\left.\text { (P) (g dwt } \mathrm{m}^{-2} \mathrm{yr}^{-1}\right)\end{array}$ & $\begin{array}{l}\text { Annual } \\
P: B\end{array}$ & $\begin{array}{l}\text { Gen- } \\
\text { eration }\end{array}$ & & $\overline{\mathrm{B}}$ & data by & $\begin{array}{l}\text { generatic } \\
\mathrm{P}\end{array}$ & & : B \\
\hline $1.82(1.68)$ & $5.58(8.24)$ & $3.06 \quad(4.9)$ & $\begin{array}{l}B \\
C \\
D\end{array}$ & $\begin{array}{l}0.78 \\
1.04\end{array}$ & $\begin{array}{l}(0.679) \\
(1.0) \\
(0.687)\end{array}$ & $\begin{array}{l}0.732 \\
5.04\end{array}$ & $\begin{array}{l}(3.403) \\
(5.044) \\
(3.396)\end{array}$ & $\begin{array}{l}0.94 \\
4.85\end{array}$ & $\begin{array}{l}(5.01) \\
(5.04) \\
(4.94)\end{array}$ \\
\hline
\end{tabular}

for the same period as Generation B of the previous year and the maximum lengths attained by this generation were similar to those of Generation B. A density estimation for Generation D in October 1984 was determined by plotting $\log _{10} \mathrm{~N}$ of this generation against time which gave a straight line from which the value of $\mathrm{N}\left(630 \mathrm{~m}^{-2}\right)$ was calculated (Crisp 1984). Results calculated as biomass and production are given in brackets in Table 2.

\section{DISCUSSION}

Parhyale basrensis, in the Shatt al-Arab River, has a high annual mean density $\left(3842 \mathrm{~m}^{-2}\right)$ when compared with amphipod species from other areas (Table 3). The peak of abundance of this species in early summer (12 $512 \mathrm{~m}^{-2}$ ) was due to the presence of 3 generations at the same time. Generation B was produced by Generation $\mathrm{A}$, whereas Generation $\mathrm{C}$ was due to the breeding activities of Generation B (Ali \& Salman 1986). The reduction of growth rate of Generation $B$ during May and June 1983 was due to its attainment of the reproductive state and production of Generation C. Generation $C$ exhibited very slow growth during the period May to September 1983. This is probably an artifact of analysis caused by the presence of several overlapping cohorts of Generations B and $C$ at the same time and the failure of the method of cohort analysis to separate

Table 3. A comparison of population density and production of different species of amphipods from different localities

\begin{tabular}{|c|c|c|c|c|c|}
\hline Species & Locality & $\begin{array}{c}\text { Density } \\
\text { (ind } \\
m^{-2} \text { ) }\end{array}$ & $\begin{array}{c}\text { Production } \\
\qquad(g d w t \\
\left.m^{-2} y^{-1}\right)\end{array}$ & $\mathrm{P}: \mathrm{B}$ & Source \\
\hline Ampelisca agassizi & Georges Bank, USA & & 2.24 & 1.5 & Collie $(1985)$ \\
\hline A. araucana & Coast of Chile & & 5.8 & 1.9 & Carrasco \& Arcos (1984) \\
\hline A. brevicornis & North Sea & & 1.0 & 4.0 & Klein et al. (1975) \\
\hline A. brevicornis & Isle of Man, UK & & $1.3-1.7$ & $2.5-3.2$ & Hastings (1981) \\
\hline A. spinipes & Coast of Brittany, France & & 0.2 & 2.4 & Glemarec \& Menesguen (1980) \\
\hline A. tenuicornis & North Sea & & 0.2 & 3.4 & Sheader (1977) \\
\hline Corophium robustum & Lower Dnieper, USSR & $1-12250$ & $5.3-101.5$ & $0.8-3.0$ & Bortkevitch et al. (1984) \\
\hline C. volutator & Swedish coast & & $2.0-4.0$ & $3.0-4.0$ & Birklund (1977) \\
\hline C. volutator & German Wadden Sea & $5-20000$ & & & Linke (1939) \\
\hline C. volutator & Swedish West coast & $8-45000$ & $1.5-30$ & $5.1-11.3$ & Moller \& Rosenberg (1982) \\
\hline C. volutator & Danish East coast & 7000 & & & Muss (1967) \\
\hline C. volutator & Danish Wadden Sea & 3000 & & & Smidt (1944) \\
\hline Encthonus fasciatus & Georges Bank, USA & & 2.28 & 4.4 & Collie (1985) \\
\hline Eogammarus confervicolus & British Columbia & $3603 \& 6233$ & $6.4 \& 21.5$ & & Stanhope \& Levings (1985) \\
\hline $\begin{array}{l}\text { Crangonyx richmondensis } \\
\text { occidentalis }\end{array}$ & Marion Lake, British Columbia & 283 & 1.64 & & Mathias (1971) \\
\hline Gammarus pseudolimnaeus & Valley Creek, USA & & 27.1 & & Waters \& Hokenstrom (1980) \\
\hline Gammarus pulex & Danish Spring & $880-5440$ & 3.8 & 2.03 & Iversen \& Jessen (1977) \\
\hline Hyale barbicornis & Tokyo Harbour, Japan & $13400-368800$ & & & Hiwatari \& Kajihara (1984) \\
\hline Hyalella azteca & Marion Lake, British Columbia & $75 \& 1952$ & $0.83-1.74$ & & Mathias (1971) \\
\hline Talorchestia capensis & Eastern Cape, South Afrnca & $52-1313$ & $2.9-7.2$ & 2.25 & van Senus \& McLachlan (1986) \\
\hline T. margaritae & Venezuela & $5692-39047$ & & & Venables (1981) \\
\hline T. quoyana & New Zealand & 256 & & & Fincham (1977) \\
\hline Orchestia tuberculata & Chile & 1000 & & & Duarte $\{1974\}$ \\
\hline Parhyale basrensis & Basrah, Iraq & $928-12512$ & 5.58 & 3.06 & Present study \\
\hline Pontoporeia affinis & Baltic Sea & & 3.2 & 1.9 & Cederwall (1977) \\
\hline P. femorata & Baltic Sea & & 3.0 & 1.4 & Cederwall (1977) \\
\hline P. femorata & Nova Scotia & & $2 . \varepsilon 3 . \vec{\jmath}$ & $3.6-4.8$ & Wildish \& Peer (1981) \\
\hline Unciola inermis & Georges Bank, USA & & 2.79 & 2.5 & Collie (1985) \\
\hline
\end{tabular}


them. The rise in growth rate of Generation $\mathrm{C}$ during September to November 1983 may indicate the absence of the interference of cohorts of new releases. Hence it may represent a good estimate of growth rate.

There were no appreciable differences in growth rates of Generations B and $C$ taken over their whole life span, as growth rates were 0.027 and $0.026 \mathrm{~mm} \mathrm{~d}^{-1}$ for males and females of the former generation and 0.024 and $0.019 \mathrm{~mm} \mathrm{~d}^{-1}$ for males and females of the latter. Individuals of the short-lived Generation $B$ did not attain the maximum size for this species, while individuals of the long-lived Generation $C$ reached a relatively large size. On the other hand the daily growth rate in terms of dry weight of Generation $C$ was higher $\left(0.0095\right.$ against $\left.0.0056 \mathrm{mg} \mathrm{d}^{-1}\right)$. This is because growth in weight is not isometric with growth in length and individuals of Generation $C$ reached larger sizes than those of Generation B. This also results in a higher mean annual biomass of Generation $C\left(1.04 \mathrm{~g} \mathrm{~m}^{-2}\right)$ than that of Generation $B\left(0.78 \mathrm{~g} \mathrm{~m}^{-2}\right)$. The mortality rates of Generation B derived from Fig. 6 are most certainly an underestimate. This is due to the fact that the peak of release of juveniles of this generation in April 1983 was overlooked and the time-lag between the samples of 11 Apr and 11 May 1983 was quite enough for these hatchlings to achieve maturity. The recruitment of this generation was therefore determined by multiplying the density of mature females (over $4 \mathrm{~mm}$ total length) in April 1983 by the brood number of the average-sized females (Wildish \& Peer 1981). Using fecundity data previously reported (Ali \& Salman 1986), the density of hatchlings was estimated to be $8000 \mathrm{~m}^{-2}$. This implies that about $77 \%$ of the deaths of this generation occurred between $11 \mathrm{Apr}$ and $11 \mathrm{May}$ 1983. Moreover the instantaneous mortality rate will then be $0.205 \mathrm{yr}^{-1}$ and the annual mortality rate $0.185 \mathrm{yr}^{-1}$, which are quite comparable with the values obtained for Generation C.

In contrast the mortality among Generation $C$ was very low at the beginning of its life. A mortality peak occurred in October to December 1983 when about $78 \%$ of the individuals died.

Available data from the literature on amphipod productivity from different localities (Table 3) shows that Parhyale basrensis is one of the most highly productive species. It ranks next to Corophium robustum of the Lower Dnieper, USSR (Bortkevitch et al. 1984), Gammarus pseudolimnaeus of Valley Creek, USA (Waters \& Hokenstrom 1980), Eogammarus confervicolus of British Columbia (Stanhope \& Levings 1985) and Corophium volutator of the Swedish west coast (Moller \& Rosenberg 1982). Furthermore, P. basrensis is a multivoltine species and the data obtained here agree very much with the conclusion of Rigler \& Downing (1984) that multivoltine species have higher rates of production than do univoltine species.
Acknowledgements. The authors thank Dr N. A. Hussain, Director General of the Marine Science Centre, for laboratory facilities.

\section{LITERATURE CITED}

Ali, M. H., Salman, S. D. (1986). The reproductive biology of Parhyale basrensis Salman (Crustacea, Amphipoda) in the Shatt al-Arab River Estuar coast. Shelf Sci. 23: 339-351

Birklund, J. (1977). Biomass, growth and production of the amphipod Corophium insidiosum Crawford, and preliminary notes on Corophium volutator (Pallas). Ophelia 16: 187-203

Bortkevitch, L. V., Khmeleva, N. N., Sadovskaya, N. I. (1984). Ecological characteristics, caloric value and production of Corophium robustum (Amphipoda, Corophiidae) from the Lower Dnieper. Hydrobiological J. 20 (2): 93-99

Carrasco, F. D., Arcos, D. F. (1984). Life history and production of a cold temperate population of the sublittoral amphipod Ampelisca araucana. Mar. Ecol Prog. Ser. 14: 245-252

Cassie, R. M. (1954). Some uses of probability paper in the analysis of size frequency distributions. Aust. J. mar Freshwat. Res. 5: 513-522.

Cederwall, H. (1977). Annual macrofauna production of a soft bottom in the northern Baltic Proper. In: Keegan, B. F. O'Ceidigh, P., Boaden, P. S. S. (ed.) Biology of benthic organisms. Pergamon Press, Oxford, p. 155-164

Collie, J. S. (1985). Life history and production of three amphipod species on Georges Bank. Mar. Ecol. Prog. Ser. 22: $229-238$

Crisp, D. J. (1984). Energy flow measurements. In: Holme, N A., Mclntyre, A. D. (ed.) Methods for the study of marine benthos. IBP Handbook No. 16. Blackwell, Oxford, p. 284-372

Duarte, W E. (1974). Orchestiodes tuberculata Nicolet, 1840 as an organism which disintegrates algae (Crustacea, Amphipoda, Talitridae). Mus. nac. His. nat. Not. mens. (Santiago) 19: 3-9

Fincham, A. A. (1977). Intertidal sand-dwelling peracarid fauna of North Island, New Zealand. N.Z. Jl mar. Freshwat. Res. 11. 677-696

Glemarec, M. A., Menesguen, A. (1980). Functioning of a muddy sand ecosystem: seasonal fluctuations of different trophic levels of the dominant macrofaunal species. In: Tenore, K. R., Coull, B. C. (ed.) Marine benthic dynamics Univ, of South Carolina Press, Columbia, p. 49-68

Harding, J. P. (1949). The use of probability paper for the graphical analysis of polymodal frequency distributions. J. mar. biol. Ass. U.K. 28: 141-153

Hastings, M. H. (1981). The life cycle and productivity of an intertidal population of the amphipod Ampelisca brevicornis. Estuar. coast. Shelf Sci. 12: 665-677

Hiwatari, T., Kajihara, T (1984). Population dynamics and life cycle of Hyale barbicornis (Amphipoda, Crustacea) in a blue mussel zone. Mar. Ecol. Prog. Ser. 20: 177-183

Iversen, T. M., Jessen, J. (1977). Life-cycle, drift and production of Gammarus pulex L. (Amphipoda) in a Danish Spring. Freshwat. Biol. 7: 287-296

Klein, G., Rachor, E., Gerlach, S. A. (1975). Dynamics and productivity of two populations of the benthic tube-dwelling amphipod Ampelisca brevicornis (Costa) in Helgoland Bight. Ophelia 14: 139-159

Linke, O. (1939). Die Biota des Jadebusenwattes. Helgoländer wiss. Meeresunters. 1: 201-348

Mathias, J. A. (1971). Energy flow and secondary production 
of the amphipods Hyalella azteca and Crangonyx richmondensis occidentalis in Marion Lake, British Columbia. J. Fish. Res. Bd Can. 28: 711-726

McLusky, D. S. (1971). Ecology of estuaries. Heinemann Educational Books, London

Moller, P., Rosenberg, R. (1982). Production and abundance of the amphipod Corophium volutator on the West Coast of Sweden. Neth. J. Sea Res. 16: 127-140

Muss, B. J. (1967). The fauna of Danish estuaries and lagoons. Meddr Danm. Fisk.-og Havunders., N.S. 5: 1-316

Rigler, F. H., Downing, J. A. (1984). The calculation of secondary productivity. In: Downing, J. A., Rigler, F. H. (ed.) A manual on methods for the assessment of secondary productivity in fresh waters. IBP Handbook No. 17. Blackwell, Oxford, p. 19-58

Salman, S. D. (1986). Parhyale basrensis, a new species of talitrid amphipod from the Shutt al-Arab region, Iraq. Crustaceana 50: 287-294

Sheader, M. (1977). Production and population dynamics of Ampelisca tenuicornis (Amphipoda) with notes on the biology of its parasite Sphaeronella longipes (Copepoda). J. mar. biol. Ass. U.K. 57: 955-968
Smidt, E. L. B. (1944). The effects of ice winters on marine littoral faunas. Folia geogr dan. 2: 1-36

Stanhope, M. J., Levings, C. D. (1985). Growth and production of Eogammarus confervicolus (Amphipoda, Anisogammaridae) at a Log Storage Site and in areas of undisturbed habitat within the Squamish Estuary, British Columbia. Can. J. Fish. Aquat. Sci. 42: 1733-1740

van Senus, P., McLachlan, A (1986). Growth, production, and a partial energy budget for the amphipod Talorchestia capensis (Crustacea, Talitridae) in the Eastern Cape, South Africa. P.S.Z.N. Mar. Ecol. 7 (2): 165-179

Venables, B. J. (1981). Aspects of the population biology of Venezuelan beach amphipod Talorchestia margaritae (Talitridae) including estimates of biomass and daily production and respiration rates. Crustaceana 41: 271-285

Waters, T F., Hokenstrom, J. C. (1980). Annual production and drift of the stream amphipod Gammarus pseudolimnaeus in Valley Creek, Minnesota. Limnol. Oceanogr 25: $700-710$

Wildish, D. J., Peer, D. (1981). Methods for estimating secondary production in marine amphipoda. Can. J. Fish. aquat. Sci. 38: 1019-1026

This article was submitted to the editor; it was accepted for printing on August 7, 1987 